\title{
Juridical Aspects of Nullify of Marriage due to Breast-Feeding in Religious Court
}

\author{
Puspita Jian Andrina \\ Suraji \\ Muhammad Rustamaji \\ Student of Notary Master Program \\ Law Faculty, Universitas Sebelas Maret, Surakarta
}

\begin{abstract}
The research aimed to describe basis of judge's decision in juridical view to grant declaration of nullify of marriage according to breastfeeding and factors that underlying judge's decision and evidence that done in it. The reasons of forbiden due to breastfeeding or nasab marriage are called mahram muabbad. Where the marriage in blood relation could be inherit genetic traits and immune strength even causes disease family. The legal research attempted to understand and know the simptoms that was studied, then connected or combined legal materials that relevant and being references in literature legal research. Based on results and discussions had came up conclusions that legal consideration that causes nullify of marriage occured in religious court is due to a marriage in one breastfeeding.
\end{abstract}

Keywords: nullify of marriage, breastfeeding relation, religious court.

\section{A. Introduction}

Every human being has the nature to settle and having children. Being a family is also a human right that must be protected by the state and the community itself, as regulated in Article 28B Paragraph (1) of 1945 Constitution of the Republic of Indonesia, which states that: "Everyone has the right to have a family and carry on their offspring through legitimate marriage".

Having a happy and lifelong family is everyone's dream and wish. To make a prosperous and happy family, as stated in Article 28B Paragraph (1) of 1945 Constitution of the Republic of Indonesia, a marriage between man and woman is required. Marriage is a spiritual bond between a man and a woman as husband and wife with the aim of forming a happy and good family or household based on Almighty God. A marriage is legal if it is carried out according to the laws of each religion and belief. Marriage that is done legally results in the occurrence of promiscuity between men and women with respect according to man's position as an honored soul. (Basyir, 1999)

Marriage is an agreement that contains the character and traits that is sacred to live together between a man and a woman in this case represented by his guardian (Pohan, 1996) Marriage or wedding according to Islamic law is a contract or agreement. As an agreement, the marriage has several characteristics, as follows: (Muzamil, 2006)Marriage or wedding cannot be carried out without consent;

1. Each party is bound by their rights and obligations;

2. Provisions in the agreement can be changed in accordance with the agreement each party, as long as it does not violate the limits set by law.

The strength of a marriage that is upheld and fostered by husband and wife is very dependent on their will and intention who are married. Therefore, in a marriage it takes the existence of body and soul love between husband and wife. Marriage that is built with unfully love then marriage this usually does not last long and ends in divorce. If the marriage has ended in a divorce, then the one who bears the consequences is the whole family. (Manan, 2006)

Bonding of body and soul is the foundation in forming and managing a happy and lifelong family, so because marriage aims to form a happy and lifelong family, it can be interpreted that the marriage must for a lifetime and should not only to be broken off. (Saleh, 1980)

Marriage law in Islam has a very important position, therefore the rules regarding marriage are regulated and explained clearly and in detail. Islamic marriage law basically does not only regulate the procedures for the implementation of marriage but also regulates all issues closely related to marriage, for example: the rights and obligations of husband and wife, regulation of assets in marriage, ways to break marriages, living expenses that must held after the breakup of marriage and others. (soemiyati, hukum perkawinan islam dan undang-undang perkawinan, 1999) 
In an ordinary agreement, termination of agreement is determined by both parties, for example because the achievement of what has become the principal of the agreement or because time limit specified has expired, so it does not take place continuously. Conversely, marriages do not know time limit, marriages must be for lifetime, except for some reason outside the wishes of the parties, then marriage can be decided, for example by divorce or nullifying marriage. (ramulyo, 1995)

Terminate marriage is not as simple as in termination of an ordinary agreement, which has been determined earlier in the agreement contents, such as cause of breaking of marriage, procedure and consequences of termination. Unlike marriage, this is not determined by the parties, but the law determines it. Covenants in a marriage have special characteristics, including that both parties (men and women) who bind the marriage agreement have mutual rights to break the agreement based on the provisions in which the laws already exist. (soemiyati, hukum perkawinan islam dan undang-undang perkawinan, 1982)

A marriage that is nullified by the judge because the party does not complete marriage conditions or legal basis, in other words the person concerned does not fulfill it. So that the incomplete legal requirements or conditions of marriage can be declared null and void by law in accordance with existing provisions. Nullify of marriage is important to study, this is because marriage is not broken due to death or divorce, the marriage is broken because it was nullified by the court, marriage nullify will have an impact not only on the marriage partner but also affects the parties related to the marriage, such as property in a marriage and will also have an impact on children born from the marriage, especially for marriages that occur between couples who are still having a breastfeeding relationship, as happened in the case of Verdict Number: 0456 / Pdt.G / 2011 / PA.Ska.

\section{B. Results And Discussion}

\section{Legal Consideration Of Judge}

a. Headnote (facts)

Based on the marriage certificate number 92/03 / III / 2009 by Religious Affairs Department (KUA) Surakarta City which states that on March 1, 2009 between the Plaintiff and the Defendant has held a marriage contract. At the beginning of the household life between the Plaintiff and the defendant, they lived in harmony, peace and harmony until finally the Plaintiff and the defendant have a child born on March 30, 2009.

However, in 2009 their household began to broken, between the Plaintiff and the defendant, constantly disputes and quarrels arose because the defendant did not respect the Plaintiff as a legitimate husband, he was too brave and often denied the Plaintiff's sayings in order to hold good households, such as refusing to live independently from parents, the defendant often said rude and disrespectful.

Actually the Plaintiff and the Defendant in previously been in one breastfeeding, when the Plaintiff was a child who had been breastfeeding for a few months with the Defendant's parents when the Plaintiff's parents were sick.

Due to of these disputes and quarrels about since October 2010 now for 9 months, between the Plaintiff and the Defendant have lived separately, the Plaintiff left the Defendant and returned to the home of the Plaintiff's own parents with the address as mentioned above and as long as it has been absent again in an intimate relationship but the Plaintiff still met the Defendant several times to give Rp 300,000 per month.

Because of the above matters, the Plaintiff hereby submits "Talaq" divorce application to the Defendant with reasons that the Plaintiff and the Defendant continue to have disputes and there is no hope of living in harmony again in marriage with the Defendant as referred to in Article 116 letter (f) Legal Compilation Islam.

b. Demands or Petitum

The Plaintiff requests the Head of Surakarta Religious Court to examine and decide on this case to make the decision:

a) Granting the applicant's request

b) Giving permission to the Plaintiff to pronounce divorce against the Defendant in front of Surakarta Council of Religious Courts

c) Determine the cost of this case according to the applicable laws and regulations.

\section{c. Judge's Consideration}

Considering, that on the day of the hearing which had been determined by the Plaintiff and Defendant, he had come to the hearing, then the Chairman of Panel of Judge ordered the Plaintiff and Defendant to take reconciliation, but failed because the Plaintiff was absent the 1st and 2nd trials; 
Considering, that the Panel of Judges has tried to advise the Plaintiff to be patient waiting for the Defendant's conviction to reconcile with the Plaintiff, but failed, the examination was continued with the beginning of reading the Plaintiff's petition, and the Plaintiff's petition at point 5 (five) stated that the Plaintiff and the Defendant were on one breastfeeding.

Considering, that upon the Plaintiff's petition, the Defendant had given an answer that the Defendant is Plaintiff's wife, who was married in March 2009 and had obtained a child called biological child of Plaintiff and Defendant, born on March 30, 2009, was true that the Plaintiff and the Defendant had a relationship according to being informed by the biological mother of the Defendant and when the Defendant was about to marry the Plaintiff, the Defendant's biological mother did not tell the Plaintiff with the Defendant's relatives.

Considering, that the Plaintiff to emphasize the arguments of the petition has submitted written evidence in the form of:

1.Photocopy of Plaintiff's Identity Card issued by Boyolali District Head Number 3309061408870005 dated November 5, 2010, and has been "nazegelen", after it has been matched with the original and shown to the Defendant, and the Defendant confirms, then it is marked with a P.1 by Chairman of Panel Judge;

2.Photocopy of Duplicate Copy of Marriage Certificate of the Plaintiff and Defendant Number Kk.11.31.3 / PW.01 / 21 / 111 / 2011 dated March 14, 2011 issued by the Sub-District Religious Affairs Office, Surakarta City and has been "nazegelen", matched with the original, subsequently shown to the Defendant, and the Defendant confirmed, then it is marked with a P.2 by Chairman of Panel Judge;

The Plaintiff has also presented 3 (three) witnesses who are closely related to the two parties whose statements have been heard in the trial which the points as follow:

The first witness, 45 years old, worked in private sector (catering), residing in Surakarta, under his oath explaining:

1. The witness is a biological mother of the Defendant

2. The witness explained that it was true that the plaintiff was breastfeeded by the witness when the Plaintiff's parents were sick

3. The witness did not know that there was a prohibition on marriage by one breastfeeding relationship

The second witness, Suwali bin Sisworejo, 49 years old, live in Boyolali. The witness gave an explanation which was essentially as follows:

1. The Defendant was already pregnant when the Defendant and the Plaintiff got married,.

2. The witness confirmed that the Plaintiff's biological mother had breast-fed the Defendant when the Defendant's biological mother was ill.

The third witness, 47 years old, live in Boyolali, is a laborer. The witness gave the statement the points was:

1. Between the Plaintiff and the Defendant has been married for two years and after marriage living in the home of the Defendant's parents.

2. The witness confirmed that the Defendant's biological mother had breast-fed the Plaintiff when the Plaintiff's biological mother was ill.

d. Judge's Decision

Based on the facts and considerations above, the judge gave the following verdict:

1)Grant the Plaintiff's request;

2)Nullifying the marriage of the Plaintiff and the Defendant that has been recorded in Religious Affairs Office in Surakarta City with a Marriage Certificate Number: 92/03 / 111 / 2009 dated March 11, 2009 in Duplicate Copy of Marriage Certificate No: KK.11.313 / PW.01 / 21 / 111 / 2011 dated 14 March 2011;

3)Imposes the Plaintiff to pay a case fee of Rp. 361,000 (three hundred sixty one thousand rupiah).

\section{Juridical Aspects}

Forbidden marriages are people who are not allowed to do marriages. What is being discussed here is which women should not be married to a man, or conversely which men should not marry a woman. The whole is arranged in the Qur'an and in the hadith of the Prophet.

The prohibition of marriage is also contained in Article 8 of Act No. 1 of 1974 concerning Marriage, marriage is prohibited between two people who:

a. Lineage relationship;

b. Lineage relationship sideways, that is, between siblings, between a sibling grandmother;

c. Semenda relationship, such as parent in-laws, stepchildren, son-in-law and mother / father stepfathers;

d. One breastfeeding, breast-fed parents, breast-fed children, siblings breast-fed;

e. Having relatives to wives or as aunts or nieces from the wife, in the case of a married wife is more than one;

f. Having a forbidden relationship by religion or other regulations, so they can't marry. 
Prohibition of marriage which is forbidden forever in the sense that at any time and in any circumstance the man and woman may not marry. Prohibition in this form is called mahram muabbad.

As for one example in Muabbad Mahram is the marriage of siblings. Where this marriage has clearly been forbidden by shar'i for certain reasons that will bring greater harm.

Breastfeeding a child for every mother, by giving breast milk (ASI) is something that is very important for the life and survival of humans in this world. Breast milk is a staple drink and food for every newborn child. According to the results of research conducted by health experts shows that children who in their infants consume breast milk are much smarter, healthier, and stronger than children who in their childhood did not receive breast milk. (abdullah, 1993) Milk is a staple food for every newborn child. There is almost no other food that children eat, especially in the early months of their birth, therefore milk helps determine the growth and development of the newborn child.

It is not enough in terms of Islamic law alone, even medical relations are also very concerned, the presence of genes in breastfeeding people who breastfeed, where breast milk causes the formation of protective organs in breastfeeding people. When he suckles between 3 to 5 breast-fed. Therefore the milk needed to be able to form organs that function to protect the human body. So, if breastfeeding will reduce the special traits as the owner of the ASI. Therefore, he will have likeness or similarities with his siblings or sisters in terms of the traits inherited from the mother owner of ASI. It has been found that organs that function to protect the body might cause the appearance of qualities that are blessed by fellow brothers in relation to marriage. From this, we know the wisdom contained in the hadith above which forbids us from marrying siblings, those who suckle more than 5 times. Actually relationship because of one's family is determined and can be transferred because of heredity. And the causes are passed down and the genes are transferred. The point is that relationship due to transfer of genes from breastfeeding, absorbed, and combined with the gene network of breastfeeding people, or breast milk does indeed contain more than one cell, where the cell is the nucleus from human life.

Mother's milk forms the structure of the human body, making the baby's flesh grow and form bones. The Hadith of the Prophet stated that which means: "There is no law regarding breastfeeding except if breastfeeding affects bone formation and growth of flesh". (H.R. Abu Daud). This occurs when the baby only eats from breast milk. Thus the mother who is breastfeeding becomes the mother of the baby. Because the baby is part of breastfeeding mother flesh. When breastfeeding, hereditary factors and immune power carry over from breastfeeding mothers to breastfeeding children. In the baby's body these factors combine with the baby's genes. This causes genes in common between babies who are breastfed by one mother. If there is a marriage between the two, it will cause bad things in the offspring. Breast milk consists of stem cells that carry general genetic traits for father and mother. Furthermore, the traits move to the child who is breastfed. This reinforces the wisdom of the Sharia prohibition on your sibling's marriage. Because of that marriage will produce an imbalance in the immune system of children as well as other serious genetic diseases. Genetic factors are the basic capital in achieving the final outcome of the child's growth and development process.

The polemic of marriage in one breastfed above, which needs attention is the child born as a result of the marriage. generally no one when born in the world already has sin and there is no inherited sin. Biologically, no child is born without a father. Regarding the variety of mention of the status of one's own children should be addressed wisely. Children are the successors to the ideals of the struggle of the nation that have a strategic role and have special characteristics and traits that are expected to guarantee the existence of the nation and state in the future. Therefore, children have the right to get the widest opportunity to grow and develop optimally, both physically, mentally, and socially and have a noble character of child growth and development because from the womb they have the right to live. Children are the mandate and gift of Almighty God, which is inherent in their dignity and prestige as whole human beings.

The decision of the 25th NU Conference in Surabaya on 20-25 December 1971 stated that "the collection of breast milk by the hospital by mothers given to infants treated at the hospital could make mahram radha" with the following conditions: ( a) women taken from breast milk is alive, and aged 9 years old Qamariyah (approx.). (b) the baby who is given milk has not reached the age of 2 years. (c) the collection and giving of breast milk is at least 5 times. (d) all the conditions mentioned above must be absolutely valid (real). (Djamaluddin miri, 2004) "Radha'ah and its Problems in the Modern World" is said that when breast milk absorbed a baby's body absolutely, which means in any way the breastfeeding process is carried out then the breastfeeding can lead to mahram law. (Noorwahidah, 1996)

According to Ibn Hazm, what is meant by radha 'in Quran and the hadith of the Prophet above is breastfeeding which is done by directly sucking the mother's nipples in accordance with zahirayat which laying the law on the irda'. Thus Ibn Hazm gives a criterion in radha 'that is the process of breastfeeding which is carried out on the mother's breast directly, and outside of that method is not included in the concept of radha' which can have legal consequences. 
Ibn Hazm's opinion was also supported by Imam Ahmad that breastfeeding can cause marital relations between children and breastfeeding mothers if the breastfeeding process is carried out by way of direct breastfeeding. Related to breast Milk, Abu Hanifah, Hanafiyah and Ibnu Qasim groups argue that the process breastfeeding requires the existence of pure milk from a mother absolutely, meaning that the milk must not be mixed with other breast milk or mixed with other substances. So if milk has been mixed with water or something else then it is drunk by a baby, then it does not belong to the category of radha 'which can lead to relationship. Abu Hanifah also gave criteria for the existence of a woman's breast milk is still in the form of fluid, that is, does not change from its original form. Therefore, if the milk is dried or hardened, for example in the form of cheese, milk powder or others, then the process of consuming this kind of breast milk can not cause mahram, because the traits of radha is no longer visible in such conditions. Consuming breast milk that has been in the form of cheese, powder or somethings like that cannot be called irda (breastfeeding).

The existence of marriage in one breastfeeding case can be seen that the lack of public knowledge related to the laws and regulations that apply even in the context of religion, both the Qur'an and al-Hadith, which regulations are prohibited and not allowed. Then in matters like this who should be more responsible? The government especially law enforcement or religious leaders in the area. The general public's lack of understanding can be caused by the lack of attention from the government and even religious leaders. This can be interpreted as a weakness of the effectiveness of law in society.

\section{References}

abdullah, a. h. (1993). keutamaan air susu ibu. jakarta: fikahati aneska.

Basyir, A. A. (1999). Hukum Perkawinan Islam. yogyakarta: UII Press.

Djamaluddin miri, a. a.-f. (2004). solusi problematika aktual hukum islam. surabaya: lajnah ta'lif wan nasyr.

Manan, A. (2006). Aneka masalah hukum Perdata Islam Di indonesia. jakarta: kencana.

Muzamil, M. (2006). Hukum Perkawinan Menurut Undang-Undang Perkawinan dan Perkembanganya Dalam

Kompilasi Hukum Islam. semarang : Unissula Press.

Noorwahidah. (1996). rada'ah dan problemnya dalam dunia modern. jakarta: pustaka firdaus.

Pohan, R. s. (1996). Hukum Orang dan Keluarga. Surabaya: Airlangga University Press.

ramulyo, s. g. (1995). hukum perkawinan, hukum kewarisan, hukum peradilan agama dan zakat menurut hukum islam . jakarta: sinar grafika.

Saleh, K. W. (1980). Hukum perkawinan indonesia . jakarta: Ghalia indonesia.

soemiyati. (1982). hukum perkawinan islam dan undang-undang perkawinan. yogyakarta: liberty.

soemiyati. (1999). hukum perkawinan islam dan undang-undang perkawinan. yogyakarta: liberty.

soemiyati. (1999). hukum perkawinan islam dan undang-undang perkawinan. yogyakarta: liberty. 